\title{
Archaeonautica
}

Archaeonautica

L'archéologie maritime et navale de la préhistoire à

l'époque contemporaine

$20 \mid 2018$

De re navali : Pérégrinations nautiques entre Méditerranée et océan Indien

\section{The Use of Ribbands in the Recent Shipbuilding Tradition}

L'utilisation des lisses dans la construction navale traditionnelle d'époque récente

Kostas Damianidis

OpenEdition

Journals

Electronic version

URL: http://journals.openedition.org/archaeonautica/571

DOI: 10.4000/archaeonautica.571

ISSN: 2117-6973

Publisher

CNRS Éditions

Printed version

Date of publication: 6 December 2018

Number of pages: 183-194

ISBN: 978-2-271-12263-6

ISSN: 0154-1854

Electronic reference

Kostas Damianidis, "The Use of Ribbands in the Recent Shipbuilding Tradition », Archaeonautica [Online], 20 | 2018, Online since 30 April 2020, connection on 30 April 2020. URL : http:// journals.openedition.org/archaeonautica/571; DOI : https://doi.org/10.4000/archaeonautica.571

Archaeonautica 


\title{
THE USE OF RIBBANDS in the ReCEnt Shipbuilding Tradition
}

\author{
Kostas DAmIANIDIS
}

\begin{abstract}
An enquiry into the use of ribbands is related to the more general issue of the process of geometric conception of a hull's forms as a function of different architectural systems. With this in mind we shall attempt a historiographical review of the main research contributions to the study of this question by archaeologists, historians and ethnologists. Thus we shall mention the "frame first ", "shell first » and " mixed » construction concepts, as swell as the notion of " active » and " passive » frames. Particular attention is paid to the information provided by the " technical recipe books » of Venetian tradition (Michele da Rodi, Zorzi Trombetta et al.), which refer to a carvelbuilt, "frame first » architectural principle. Certain aspects are more specifically mentioned, such as the definition of a « dimensional and proportional sketch » of the hull, as an aid to the form conception process, and the complementary geometric figure of the main frame (with $X$ and $Y$ values and tangent arcs). From this, several «transversal » form conception processes based upon the main frame are presented by comparing textual and ethnographic data. In all cases, these " transversal » conception processes are complemented by " longitudinal » conception processes realised on the building berth by construction ribbands. Four types of ribband are principally used: flexible ribbands running along the entire length of the hull which are attached to frames that have been pre-determined by means of the master-mould, rising square and breadth staff method, and which serve to define the non-templated frames; wide and rigid partial ribbands that act as stays to maintain the frames in place temporarily during construction; supple ribbands (sometimes replaced by string) designed to determine the bevel angle on the external side face of frames; and ribbands in the form of battens used to define the size and shape of the planking. As regards the difficulties in interpreting written and archaeological sources, ethnographic data gathered during research in traditional shipyards provide the essential keys.
\end{abstract}

\section{Key words}

Conception, «Frame » construction, Ethnography, Hull forms, Construction ribbands
L'UTILISATION DES LISSES DANS LA CONSTRUCTION NAVALE TRADITIONNELLE D'ÉPOQUE RÉCENTE

\section{Résumé}

Cette question de la fonction des lisses est à relier à celle, plus globale, des processus de conception géométrique des formes des coques en fonction des différents systèmes architecturaux. Dans cette perspective, un rappel historiographique des principaux apports des recherches d'archéologues, d'historiens et d'ethnologues à l'étude de cette question est entrepris. C'est ainsi que sont évoqués les concepts de construction "sur membrure", "sur bordé », de construction " mixte », ou encore de membrure « active » et « passive »... Une attention particulière est portée aux données fournies par les « livres de recettes techniques » de tradition vénitienne du xve siècle (Michele da Rodi, Zorzi Trombetta...) qui renvoient à une architecture à franc-bord de principe "sur membrure ». Quelques aspects sont plus spécifiquement mentionnés comme la définition d'une " esquisse dimensionnelle et proportionnelle » de la coque, support du processus de conception des formes, et celle, complémentaire, de la figure géométrique de la maîtresse-section (par abscisses et ordonnées puis par arcs de cercle tangents). Sur ces bases, plusieurs processus de conception " transversale » des formes à partir de la maîtresse-section sont présentés en confrontant données textuelles et données ethnographiques. Dans tous les cas de figure, ces processus de conception «transversale »sont complétés par des processus de conception de nature "longitudinale » matérialisés sur le chantier par des lisses de construction ou d'exécution. Quatre types de lisses sont principalement attestées : des lisses flexibles disposées sur toute la longueur de la coque prenant appui sur les membrures prédéterminées au moyen, notamment, de la méthode du maître-gabarit, de la tablette d'acculement et du trébuchet, et servant à définir les membrures non gabariées; des lisses partielles, larges et rigides, agissant comme des étais pour maintenir provisoirement en place les membrures pendant la construction; des lisses souples (parfois remplacées par un cordeau) destinées à déterminer l'équerrage de la face externe de droit des membrures; des lisses en forme de lattes utilisées pour la définition du brochetage des bordages. Au regard des difficultés d'interprétation des sources écrites et archéologiques, les données ethnographiques recueillies lors d'enquêtes dans des chantiers navals traditionnels fournissent des clefs essentielles de lecture.

Mots-clés

Conception, Construction «sur membrure », Ethnographie, Formes de carène, Lisses de construction 
Several papers on the interpretation of ancient shipbuilding have been published during the last decades. Undoubtedly the plethora of shipwrecks that have been excavated and studied or they are currently under study composes a substantial database, which set the ground for new comparisons on the interpretations of old shipbuilding techniques.

The discussion started several decades ago, among the scholars interested in the evolution of shipbuilding concerning specifically the process of « designing » or « controlling » or « forming » the shape of the vessels during their construction. First Olof Hasslöf (1963, p. 162-177) with the study between carvel and clinker planking and the distinction between shell-first and skeleton-first construction and later Lucien Basch (1972, p. 15-49) with the ideas of « active » and « passive » frames on the construction of ships, have worthily been considered as the main initiators of this discussion. Despite the obvious interpretation of the frames of the shellfirst structure as « passive » and those of the skeleton-first structure as « active », Basch continued by introducing the term « intermediary techniques » in which « active » and « passive » frames coexist in the structure of a single hull. Therefore he introduced, perhaps indirectly, the concept of « mixed construction-processes » where shell-first and frame-first « shape-controlling » elements coexist (Basch 1972, p. 29-34).

Working further on this idea we can think that the same principle of « active » and « passive » components could be extended to other members of the structure like internal longitudinal components, through beams or even ordinary strakes. It is true that in the process of « controlling » the shape of early hulls there were, as well, other components than frames that were contributing to the configuration of the ship-shape, like strakes or their counterpart ribbands (or provisional battens).

Patrice Pomey (1998, p. 64) identified this kind of « active strake » in some of the shipwrecks that he excavated. He calls them « adjustment strakes » (virures de réglage), as in the planking of the archaic shipwreck Jules-Verne 7 (end of the $6^{\text {th }}$ century BC) that were used to correct the symmetry of the hull. In Jules-Verne 7 the asymmetry of the seven first strakes of the planking (we can call them « passive » strakes) was fairly corrected (though it is not specified the kind of asymmetry of the planking that corrected) at the level of the eighth strake, which is larger that the others and which carries arrow-shaped construction marks (we can call it an « active » strake). The eighth strake plays a role of adjustment in the configuration of the shape of the hull and Pomey (2009, p. 59) called it « adjustment strake » because a check of the shape of the hull was performed at this level. However Jules-Verne 7 was not the only shipwreck where « active strakes » or « adjustment stakes » were identified. Strakes of similar function seem to have been used in other ancient hulls like the Kyrenia ship ( $4^{\text {th }} \mathrm{c}$. BC, Steffy 1994, p. 42-59), the Madrague de Giens ship (75 - 60 BC, Pomey 1998, p. 64) and Yassi Ada II (4 ${ }^{\text {th }}$ c. AD, Bonino 2012, p. 130-131). The vestiges of Fiumicino 4 ( $3^{\text {rd }}$ c. AD) do not confirm the existence of a similar « adjustment strake » rather than the use of a group of five planks, on each side of the lower part of the hull. This group were shaped with planks of pointed extremities (stealers) in order to materialize an overall symmetrical sheer line, at the level of the fifth plank, on both sides of the hull (Boetto 2006, p. 112-126). These identifications of « adjustement strakes » or « active strakes » in several ancient hulls look like a contradiction to the idea of the simultaneous potentially existence of « active frames » in some hulls. However the idea of a mixed pattern, where both « active frames » and « active strakes » coexist, was recently proposed by Marco Bonino (2012, p. 131) in which the « active » or
« reference » frames and strakes form a kind of « geometric cage » that controls the overall shape of the hull and into which the other « elements of the construction were fitted, to fill the space left».

In the first two decades of this discussion there were a few other publications that continued with new ideas about the determination of ship-shapes in Antiquity. Probably the analysis of scantlings of the $11^{\text {th }}$ century Serçe Limani by Richard Steffy (1995, p. 417-428) and the following arguments on the Mediterranean shell to skeleton transition (Steffy 1991, p. 1-9) were the new data that gave fresh impetus to discussion. Steffy for the first time demonstrated the identification of a measuring system in the structure of the boat that based on the multiplication of a reference unit of c. $320 \mathrm{~mm}$ (approximately the late Byzantine foot of $312 \mathrm{~mm}$ ). Furthermore he proposed a system to determine the shape of the boat, applied in the first step of skeleton assembly. That was the axis of stempost - keel - sternpost together with two main frames and eight floor timbers mounted rigidly on the keel before any other component. He proposed specifically a spaced location of these floor timbers which were « similar to amidships floor, but with an additional deadrise at the bilge and a narrowing throughout ». Steffy implied that with all these initial « active » components together with some measuring ratios, based on the reference unit, the shipwright was able to set the first visualized control of the potential ship-shape. This was a ground-breaking interpretation of the restoration of « controlling » the assembling of the hull of the Serçe Limani shipwreck. It seems necessary though, that to these initial « active » components we have to add two or more couples of ribbands in order to calibrate the final position of the « active » floor timbers and frames and to visualize the whole concept of the form of the boat. Steffy's ideas were refreshed about two decades later by Mathew Harpster (2010, p. 44-55) and extended into the application of a specific moulding system with adjustable templates « potentially used to design the floor-timbers and the tail-frames that manifested the Serçe Limani ship ». Harpster (2009, p. 297-313) even identifies almost the same system of initial configuration components together with a reference unit of $345 \mathrm{~mm}$ according to an approximation of the standard Byzantine foot, in the earlier shipwreck of Bozburun, $9^{\text {th }}$ century A.D. By introducing the aid of moulds with two adjustable templates (breadth and rising mould) in the interpretation of the assembly of both ships, Harpster suggests a direct relationship of this system to some of the content of the early shipbuilding treatises from $15^{\text {th }}$ and $16^{\text {th }}$ centuries. He actually proposed, as a hypothesis, the extension of the knowledge of the Venetian ship-designing system of partison well into the Byzantine era, as early as the $9^{\text {th }}$ century. Nevertheless, edge-joints in the form of polygonal treenails ( Bozburun shipwreck. They had a cross-section of c. 10-13 mm, and penetrated c. $50 \mathrm{~mm}$ into the plank-edges (Pomey et al. 2012, p. 273). With this edge-joint with dowels on the hull of Bozburun shipwreck, the use of framing moulds with adjustable templates was apparently proposed in a mixed strake-and-frame construction method. Similar mixed methods, with a shell-built process at the bottom of the hull (edge-joint with dowels), a skeleton-built process in the upper part (nailed on the frames without any edgejoint) and a skeleton concept in the general structure (the weak joints of the shell-built bottom requires some initial skeleton structure which became more and more integrated as the structure rises), is now evident in the majority of the Yenikapi shipwrecks. They are dated from $9^{\text {th }}$ to the beginning of the $11^{\text {th }}$ centuries AD (Pomey et al. 2012, p. 279-285; Pulak et al. 2013, p. 29-33 and Özsait Kocabaş, 2008, p. 97-183). Thus the idea of moulds with 
adjustable templates for successive moulded frames and ribbands could well be potentially investigated into the Byzantine era. However moulded frames were directly identified in another shipwreck from the end of the $13^{\text {th }}-$ beginning of the $14^{\text {th }}$ centuries from Culip VI in Spain (Rieth 2003b, p. 9-16) and this is a unique archaeological testimony that a great part of floor timbers of the ship has been moulded by means of the method of master-mould and rising staff (Rieth 2009b, p. 353).

Marco Bonino (2012, p. 120-133) reconsidered the ideas of « active » frames, « active » strakes and adjustable moulds in the reconstruction of ancient hulls. He calls all of them « geometric operators » and he identifies, first, a measuring system in the basic dimensions of several shipwrecks when they have main dimensions based on an approximation to the Roman foot (values from 294 to $296.6 \mathrm{~mm}$ ) obtained by trial-and-error. Then he introduces an analysis of hull geometry for selected shipwrecks where he identifies a rational sequence of arcs and segments in potentially « active » frames, and parts of ellipses and sinusoids in potentially « active » (reference) longitudinal components (strakes, wales or sheer planks). He introduces the distinction between « geometric operators » (references), which were materialized components of the structure (frames, strakes, wales, sheer planks, through beams) that were followed a regular geometrical pattern, and the rest of the structural elements, which were put in to fill the space left between the geometric operators. He concludes with the hypothesis that geometrical methods known from the $15^{\text {th }}$ and $16^{\text {th }}$ century treatises (named partison) were involved in the earlier shipbuilding not « for the whole cross-section[s], but only the portion covering the difference between main and active sections » (Bonino 2012, p. 132) and he probably implies that for the rest of the sections, in the bow and the stern, there were other « geometric operators » like « active strakes » or ribbands that were used for the configuration of their shape.

As we have seen in the discussion about the evolution of shipbuilding techniques and specifically the process of « designing » or « controlling » the shape of the boats there are often references to the Venetian shipbuilding treatises from the $15^{\text {th }}$ and $16^{\text {th }}$ centuries. The earliest of them, the Michele da Rodi manuscript, dated in 1434-1435, was known earlier as Fabrica di galere (Jal 1840, p. 6-30 and Anderson 1945, p. 160-167). This work was recently restudied in the light of new evidence and in comparison with the roughly contemporary text of Zorzi Trombetta da Modon (14441449) and the somewhat later in $15^{\text {th }}$ c. manuscript entitled Ragioni antique spettanti all'arte del mare et fabriche de vasselli (McGee 2009a, p. 223-249, 2009b, p. 211-241; Bondioli 2009, p. 243-280).

These manuscripts have the same principals like the above mentioned interpretation of shipwrecks as far as « designing » or « controlling » the hull-shapes are concerned, which can be codified in the three following units.

First there are rules of dimensioning and ratios for the establishment of principal dimensions; second there are cross-section oriented aids, basically for the determination of frames or moulds for framing; and third there are longitudinal oriented aids for the configuration of « shell-oriented » properties of the hulls.

Meanwhile the same three units have been recorded in recent oral traditions, from many areas of the Mediterranean (Rieth 1996, 2003a; Marzari 1998; Damianidis 1998) and beyond (Sarsfield 1988; McKee 1983, p. 118-123) and they have astonishing similarities with those from the early manuscripts. Therefore it is worth focusing on the examination of the above-mentioned units with evidence both from handwritten sources and oral testimony provided by ethnography.

\section{RULES OF DIMENSIONING AND RATIOS}

The principal dimensions of the ships or the galleys were determined by specific ratios and dimensioning rules. The initial element was probably a length. However Lane (1934, p. 90) mentioned that the beam of the ship was most frequently taken as the starting point. There are suggestions on the other hand (Loewen 2001, p. 243-244; Bonino 2012, p. 121), that the first step in designing a merchant ship might have been the desired carrying capacity. The early sources, however, make direct references to lengths. In Zorzi Trombetta da Modon, for example it is mentioned that «These measurements are of a galia sottil and she is 22 paces and 2,5 ft. long on deck... » (Anderson 1925, p. 139) and in Michele da Rodi is mentioned: «We want to make a lateen ship, whose keel we want to be 12 paces long... » (McGee 2009b, p. 220). Possibly the question of carrying capacity was the initial agreement with the shipwright but it seems that the initiation of the "designing » or « controlling » the geometry of the vessel by the shipwright was the decision of a length (keel or LOA) of the vessel. If the initial measurement was the length of the keel then the next dimensions to be determined were the beam, the depth, the LOA and the horizontal and vertical projections of the posts. In the early manuscripts they give specific measurements rather than ratios but in the recorded oral traditions the principal dimensions are usually given in rules of ratios (Damianidis 1996, p. 42, 52, 64), like « the amidships beam is about equal to LOA/3 ». Moreover it is noticeable that the same kind of dimensions, either as measurements or as ratios, are given as principals in all the sources, both in early manuscripts and in oral testimonies, namely: length of keel, LOA, amidships beam, amidships depth and projections of posts. For example, Loewen (2007 p. III-5) presents the 1:2:3 or to 2:5:7 relationships among the breadth, keel and overall length for medium and large ships, mentioned in Iberian treatises.

The next step in the process of « designing » or « controlling » or « forming » the shape of the boats during their construction is the determination of the shape of the amidships frame. This is a task that belongs to the next unit of cross-section aids but there are some rules of dimensioning integrated into it. These are measurements that correspond to the narrowing or rising of certain dimensions, like the beam or the depth, if we compare the amidships frame with a frame located about half way to one of the extremities of the hull (often they call this the «tail frame» and it is described further below). These are not considered principal measurements but they are essential, because they control the potential shape of the hull. Sometimes they were derived from some basic sketching of some lines of the boat (Damianidis 1998, p. 222) or during the assembling of the first pieces of the skeleton of the vessel. They were kept more frequently in the form of a segment marked on a stick, in real size, and sometimes they stored it in a specific place in the shipyard or more often they were used only once. It is astonishing that this kind of information concerning memoranda of some measurements was included in the work of Michele da Rodi and in other manuscripts (Bondioli 2009, p. 257-260). They were probably transferred from the sticks to the paper, each one of them called morello and it contains in almost cryptographical form an important measurement in real size.

During ethnographical fieldwork in Greek boatyards the practice of noting a small distance on a stick, in real size, has been recorded. The Greek boatbuilders call this stick (and the work of

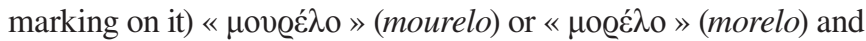
it is obviously a practice very similar to the one included in the 
manuscripts. Often this work is used during placing the ribbands in order to specify the locations for the control points for their position and symmetry. If the word morello has a Greek origin then possibly it derives from the word « $\mu$ ópiov » (morion) which has the meaning of molecule as well as particle or small segment.

\section{CROSS-SECTION AIDS}

The bulk of these aids contain moulds of various shapes of frames. Unexceptionally part of this unit is the mould for the amidships or the main frame and it is considered as the primary configuration for almost all the frames. There are two basic methods recorded in the shipbuilding treatises for the determination of the mould for the amidships frame. The first is described analytically in the manuscripts of Michele da Rodi and Zorzi Trombetta da Modon. According to this method, the shape of the mould for the amidships frame of a ship or a galley was set out by giving offsets from the centreline at intervals from the keel upwards. Ten offsets are measured on the drawing of the amidships frame for the galley of Flanders by Michele da Rodi and eight offsets on the drawing of the amidships frame of a light galley from the Zorzi Trombetta da Modon manuscript (McGee 2009b, p. 223). These are the earliest descriptions of designing moulds for a frame of a ship and it is suggested that they were taken (like extracted data) from previous seaworthy vessels (Bondioli 2009, p. 251) or they are simplified results from a more geometrical method with arcs of circles (Rieth 2009a p. 132; Barker 1998 p. 119).

The second method for the determination of the amidships frame was recorded in some shipbuilding treatises dated later than those mentioned above. Typical examples of the second method are included in Mathew Baker's early material in « Fragments of Ancient English Shipwrightry » from about 1570 (Barker 1986, p. 166) and in Portuguese manuscripts of the early $17^{\text {th }}$ century (Loewen 2001, p. 244-245). They are amidships moulds of several vessels composed by successive segments of circles (usually three or four arcs) with specific radii and locations of centres. This purely geometrical method was based on a theoretical or abstract concept in contrast to the first (earlier) practical method described above. There was a period probably during the $16^{\text {th }}$ century that both methods were in use, but later in the following century the second one appeared predominantly in the records (Barker 1998, p. 115-120, 2003, p. 67-76; Loewen 1998, p. 45-46).

In addition to the mould of the amidships frame there were moulds for assembling other frames. The simplest version of moulding was with two more moulds for frames, one forward and one aft, placed near the middle of the distances between the pair of the amidships frames and the extremities (stem and stern) of the boat. There is no reference to this simplest version in the early shipbuilding treatises but there is a description by John Patrick Sarsfield (1988) based on recorded oral testimonies concerning a « traditional carvel design and building system » from Brazil. In this description it seems that the moulds for the amidships and the two additional frames had fixed shapes and were used directly on the timbers to cut the frames. The configurations of the rest of the frames were taken off by the use of ribbands, which were placed rigidly on the amidships pair and the two other frames. It seems obvious that the method can be used only on small vessels, where the ribbands (thin flexible laths) can bridge distances between frames and posts no more than 2-3 $\mathrm{m}$. The method seems very simple and the critical elements are the shape of the amidships mould and the positioning of the ribbands. It is expected that the final positions of ribbands were justified by trial-and-error and this could involve repositioning of the frames especially the outer pair, or trimming the surface of the pre-erected frames with an adze. The desired result of this process of positioning the ribbands is the formation of fair curves all along their length.

A similar method with two more frames has been recorded in a Greek ethnological source. Poulianos (1977, p. 545), presenting the boat-building tradition of the Aegean island of Icaria, gives a description of a system of six frames, produced possibly by fixed moulds, placed in spaced positions on the keel and provide a rigid framework for the ribbands that follow. The method includes the pair of amidships frames, two of the fore and another two of the aft frames (not those adjacent to the middle pair). The moulds (especially the amidships one) are called « $\chi v \alpha ́ \varrho 1 ~ »$ or

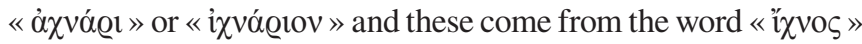
which has the meaning of footprint (Basch 1972, p. 37). The concept is the same as the Brazilian example and they are both versions of the " master frame and ribbands » method, which is classified in other publications (Sarsfield 1988; Damianidis 1998, p. 218-219). It is worth mentioning the possibility that the process described in the earliest shipbuilding treatise (the work of Michele da Rodi or the Fabrica di galere - considered identical and dated to 1434-1435) was similar to the recent Greek version of the « master frame and ribbands ». Michele da Rodi gives some measurements for the tail-frames and also for the frames eighteen feet fore and aft of the amidships frame (McGee 2009b, p. 214-215). Thus it seems that the ribbands that were placed later were mounted on the six frames and the stem and sternposts, like the version described by Poulianos. We will come back to this similarity later in the discussion about the ribbands.

The moulding methods described in other shipbuilding treatises like Zorzi Trombetta da Modon were designed to shape a group of several frames. In this case the moulded frames were located in a middle part of the vessel between two distinctive frames called «tail-frames » or « head of design ». According to Lane (1934, p. 92) these were probably the last frames fore and aft that were true floor timbers, the last U-shaped ribs. Before and abaft the tail-frames the ribs became V-or-Y-shaped, and the floor rose above the keel. In the sixteenth century the design of every fifth frame, between the tail frames, was sometimes worked out with the aid of the amidships mould and a mathematical (or geometrical) guide (diagram) called partison by the Venitians. There were several partison diagrams and they were extensively used, at least, from the $16^{\text {th }}$ century until now. They were serving the need of successive configurations of the shape of the moulded frames (with adjustable templates) in several countries and they have been extensively presented in many publications (Barker 2007, p. 68-73; Chiggiato 1991, p. 145-184; Rieth 1996, p. 133-148; Bellabarba 1993, p. 274-292; Contente Domingues, Barker 1991, p. 37-47). It is out of the scope of this paper to present extensively the partison diagrams and their use on the formation of the moulded frames. However, in the $16^{\text {th }}$ century shipbuilding treatises, in which the partison are mentioned, are almost silent about the way that the shapes of the rest of the frames (in the bow and the stern) occurred (Lane 1934, p. 88-99; Loewen 1999, p. 218-219 and Lehmann 1995). These undoubtedly include the frames between every fifth frame (that were produced by the mould and the partison diagrams) and mainly the frames located fore and aft of the tail frames. It is expected that the shape of those non-moulded frames were determined by the use of ribbands based on the experience of shipwrights. They work probably by 
trial-and-error, including, if necessary, slightly repositioning of some moulded frames and trimming the external surfaces of some others by an adze in order to achieve fair curves all along the lines of the ribbands. If this was the process likely to have occurred in the shipyards, where cross-section aids, namely moulds, were used according to the old treatises, then the final shape of a hull was determined in two phases. In the first one, it was the initial set up of the geometry of the hull, with the aid of the moulds, and in the second one, it was the final configuration of the overall form of the hull, with the aid of ribbands. Thus the produced shape of the ship was based on the pre-designed moulds. However most of the moulded frames were adjusted (repositioning of their location or trimming their external surfaces with an adze) during the visual finalization of the form in the phase of positioning the ribbands. There is not any moulding method described in any source, where the overall configuration of the hull could be materialized without the use of ribbands.

\section{LONGITUDINAL AIDS}

Ribbands were the main longitudinal aids for the « designing » or « controlling » or « forming » the shape of the boats and they were used in various shapes and forms. They are significant aids recorded both in the manuscripts and in oral traditions but it seems that they have been rather underestimated in most of the recent attempts to interpret earlier shipbuilding processes. Richard Steffy (1994, p. 278) gives the following definition: «Ribbands [Ribbons, Battens]: Long, flexible strips of wood most commonly used as temporary keepers by nailing them across the outside of standing frames while the vessel was been built. When the term «framed on ribbands» was popular in the last few centuries of wooden shipbuilding, the ribbands were sometimes carefully arranged to represent certain rising and narrowing lines, from which planking and intermediate frames shapes were derived ». In a more general sense and in relation to the various functions that ribbands were serving in the past, it can be accepted that ribbands are long strips (usually made of planks) nailed temporarily on the outside of some standing frames and used mainly to determine the shapes of some components of the structure of a vessel (mainly frames and some of the planks).

Obviously we think of them in the framework of skeleton-first assembly but undoubtedly ribbands should considered « longitudinal-guides », in the way that Steffy (1995, p. 418-419) identifies the concept behind the visualization of the hull by longitudinal bands (apparently he meant the strakes), in the shipbuilding process. The positions of the ribbands are very critical and it is the builder's skill that determines their curves and positions based on his experienced eye. All ribbands are nailed on with the attempt to have general a similar sheer line like the respective forthcoming planks at the same position. Their equivalence to some strakes of planks is so obvious that Basch (1972, p. 37) call them «pre-side-planking ». Their position and cross section depend on their function during the building process. There are not many evidence from shipwrecks concerning ribbands with the exception of the Red Bay, Labrador (1565) wreck, where clogged holes in small wooden plugs were identified on the outer faces of the ribs after a systematic examination. These holes did not correspond to any point of assembly of the carvel strakes to the frame and once mapped, they were aligned more or less in several sets interpreted as temporary ribbands fixed originally by nails. The holes of the nails were blocked, later, by small wooden pegs when disassembled the ribbands, for fixing the planks (Grenier $e t$ al. 1994, p. 139). Another example of a later shipwreck with some indication of ribbands is the La Belle a late $17^{\text {th }}$ century French ship, where the indirect evidence for the ribbands comes in the form of a series of blind treenails that align very closely with the outboard edge of the surmarks on the outboard face of a majority of the frames (Carrell 2003, p. 198).

Ribbands were possibly mentioned as early as 1273 in a document concerning the construction of a horse transport for the account of king Charles I of Anjou under the term of formis (Rieth 2009a, p. 129).

Four kinds of ribbands have been recorded in the sources. The first includes ribbands used for the determination of the overall shape of the hull and especially on the two ends. The second contains ribbands used as temporary keepers of the erected frames, especially in the middle part of a vessel. The third kind contains ribbands used to determine the bevel of the outside surface of the frames; sometimes these are ropes rather than planks. The last kind includes ribbands used to take measurements for the determination of the shape of the strakes during the planking, or other wooden components of a skeleton first hull, like the use of the spiling battens.

\section{THE FIRST KIND OF RIBBAND}

The first kind of ribband is better known and is presented briefly in several publications. References to this kind of ribbands are included in the earliest shipbuilding treatises in a way that leaves no doubts about their significance. They are presented in noticeable detail in the manuscript of Michele da Rodi and they were called maistre in early $15^{\text {th }}$ century.

Michele's section on shipbuilding provides a long list of measurements for the locations of three ribbands (on the one side of the hull). The upper one was at the sheer line, the lower one at the turn of the bilge and a third one was between the other two. The heights of the ribbands are given in the manuscript, one above the other, at the amidships frames, the 18-foot frames, the tail frames, and at bow and stern (McGee 2009b, p. 214). It is obvious in the document that ribbands were critical aids for the determination of the shape of the frames and consequently the form of the hull. In another treatise on galley construction of 1691 there is a specification that the forms « ... serve to trace out the crook timbers (fourcats) of the stern and the bow by trial and error in position, because one cannot work them at all in advance with simple moulds like the floor timbers of the bottom » (Rieth 2009a, p. 129). Some Iberian renaissance texts on shipbuilding have few passing reference on this kind of ribbands, and Loewen (2007, p. III-9) states that they were used to control the shape of the hull in a similar manner like the hull planks in shell-first construction. These kind of ribbands were used, according to Loewen (2001, p. 243-244, 250) during the construction of both Mary Rose and Red Bay vessels.

In principle, dimensions could be taken off the ribbands to make the rest of the frames, but it is noticed that simply bending the ribbands around the frames did not properly define the curves of the hull at bow and stern. Accordingly, Michele's manuscript ends the section on ribbands with two drawings labelled maistre as well (the same name as the ribbands?), one for each end of the ship (fols. 138b-139a). These drawings, in 
the manuscript, look like frames, but represent devices used to adjust the position of the ribbands at bow and stern in order to obtain the proper shapes. It is mentioned in the manuscript that the one of these devices should be placed on the stem-keel mark at the bow and the other on the stern-keel joint. These devices seem to be like temporary frames, which were located at specific positions (near the two ends) and used only to control the bending of the ribbands, in order to achieve the desirable complex shapes at the bow and the stern.

A similar process for the use of this kind of ribband has been recorded in oral testimonies during research in some living shipbuilding traditions. It is worth comparing this evidence in order to understand better what was possibly behind this meticulous description of the positioning of ribbands by Michele da Rodi.

We mentioned already the description from Brazilian boatyards (Sarsfield 1988, p. 3-4) where the ribbands are called armadouras. It is worth giving some further details about the positioning of these three ribbands as they are recorded in the source. Their positions are marked only on the two master-frames, the transom and the stern. They are placed on one side only, except the upper sheer ribband, which is placed on both sides as a symmetrical reference. The ribbands are long laths, about $25 \times 37 \mathrm{~mm}$, for a $9 \mathrm{~m}$ vessel, and sometimes they are made of two or more pieces joined together. Vertical struts also support the ribbands, so that they have the proper heights. All the remaining ribbands will be placed on one side only. The one that passes along the turn of the bilge is called armadoura mestra (master ribband) and reveals that it is considered a critical component of the design process. Since the shape of the hull forward varies dramatically in section (the stern has a transom and the lines are very smooth) it requires some additional control. This is achieved by a straight stick positioned to lie against the deadwood and against the inside face of the upper ribband. The basic assumption here being that, at some point forward where the flare begins, the half-section changes from convex to concave, and at this point there are straight lines on both sides, producing a $\mathrm{V}$ shaped frame, at this position. In touching this straight stick, which in effect is a subtle temporary mould, each ribband can assume only one position. At this stage, while the ribbands may be fair in section, they are still a bit wobbly due to their long unsupported runs fore and aft of the master frames. Quarter frames are now placed at the $1 / 4$ and $3 / 4$ positions along the keel or LOA depending on whether the masters were placed at $1 / 2$ the keel or LOA, respectively. These are the terço de vante and the terço de ré and their purpose is to stiffen the ribbands sufficiently in order to provide a ridged framework for taking off the shapes of the remaining frames, and not to define or mould hull sections. Although, after the terço de vante is in place, the ribbands are given a final readjustment because this frame usually results in bringing the ribbands closer to the hull center line.

The shape of these quarter frames, and of all the remaining frames, are taken off from the ribbands with a construction pliable rod, known as a varão, bent to follow the section contour from the sheer to the top edge of the keel. The corresponding location of the frame position at sheer level is determined by resting a straight stick across the sheer ribbands, squared to and plumbed over the keel at the correct frame position. Ribband positions are marked on the rod as reference points and so that the taper of the frames can be proportioned from keel to sheer. Next, a suitable piece of timber stock, with a natural curve corresponding to the curve of the rod, is chosen and cut down to the sided thickness of the frame. Sarsfield continued this

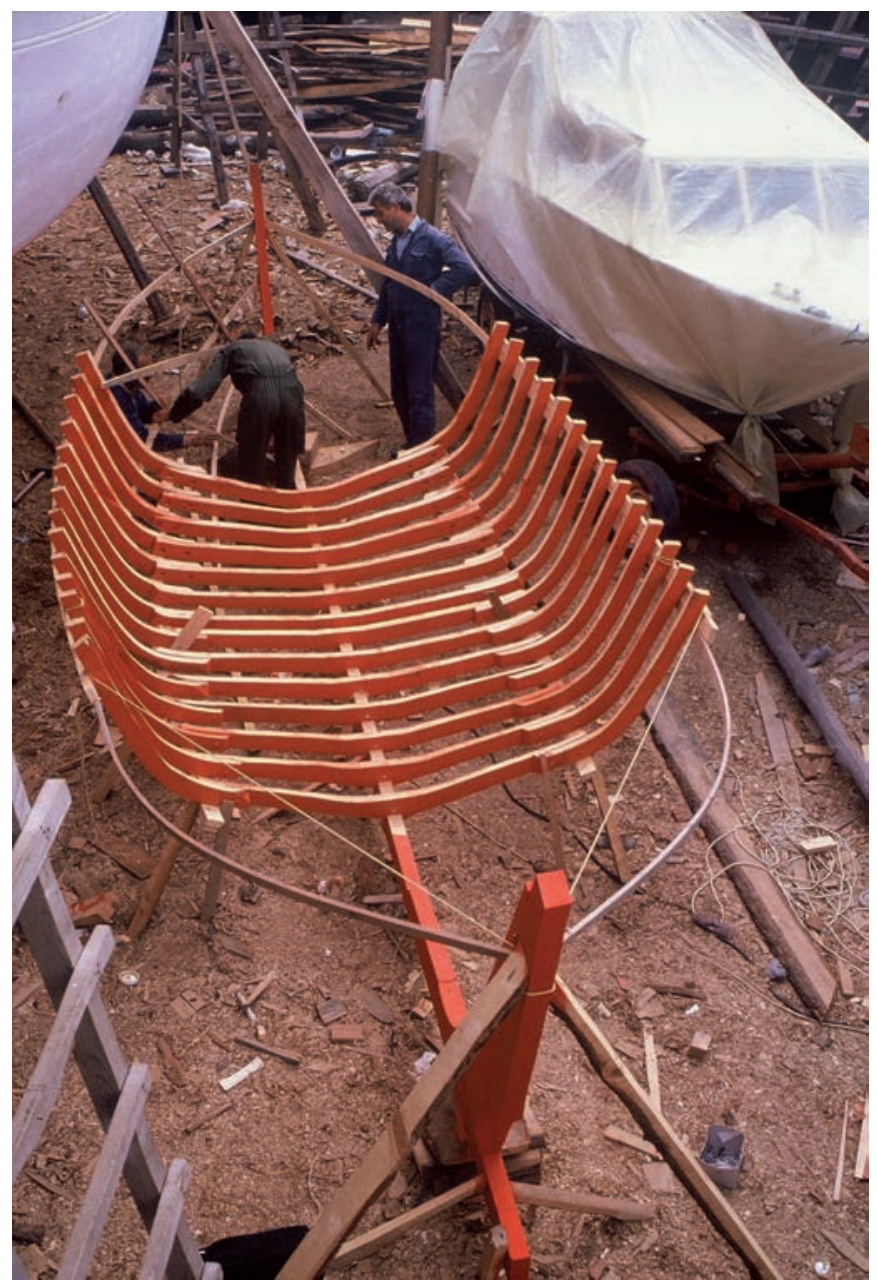

Fig 1: The frames on the middle part of the boat are shaped by "moulding with adjustable templates" method and ribbands (forma) were then placed to determine the shape of the rest of the frames. The sheer ribbands on both sides and the other two ribbands (placed only on the port side of the bow) are erected at this stage of the structure. The boatbuilders try to determine the shape of another frame, placed forward of the moulded frames, by using the ribbands of the first kind (photo K.A Damianidis, Syros 1998).

description by mentioning that vessels up to 30 metres in length were built with the same method. However it is possible that for longer vessels required some additional elements (like frames or other device) to support the ribbands rigidly.

It seems that a similar method has been recorded in Britain (McKee 1983, p. 118-123) and it was in use up to the First World War. The description does not go into many details but again the critical parts are the shape of the amidships frame and the positioning of the ribbands. McKee mentioned that « there are two adjustments to the shape of the ribbands rather like the lath in a coracle. The builder can raise or lower the ends on the posts or he can lengthen or shorten the length of the ribband. If this is not enough, he uses shores, almost as if he was constraining an edge-fastened strake before fastening. His eye will tell him when the curvature of the ribband is fair and the way he wants. This is as an important stage as the first strakes of a clinker boat as it will decide the character of the whole boat ».

In Greece (fig. 1) there are two principal methods of moulding recorded in ethnographical research and ribbands are integral parts of both. The first contain fixed frames, thus it is classified as « master frame and ribbands » and is mentioned briefly above. 


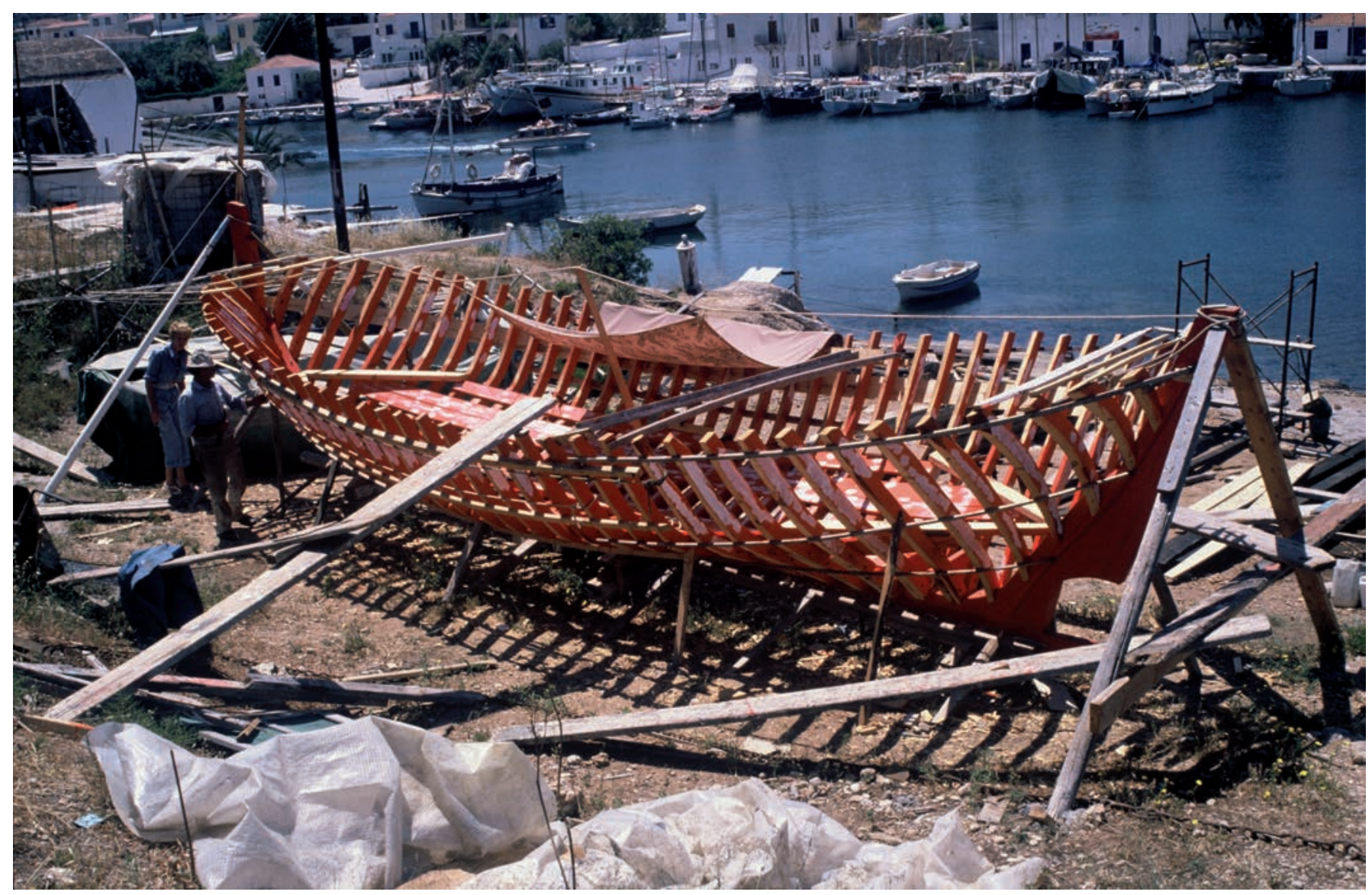

Fig 2: All the frames are erected using the moulding with adjustable templates and the three ribbands (forma) that appeared in the picture (photo K.A Damianidis, Spetses 1989).

The method, like the Brazilian example, depends considerably on the use of ribbands. All the details mentioned in the Brazilian description, above, are applied to the Greek method as well. Additionally, the pre-erected frames are the pair of amidships frames, two of the fore and another two of the aft frames, like the description by Michele da Rodi. This is the Ikarian example mentioned above, but here the two devices to adjust the position of the ribbands at the bow and the stern, that illustrated by Michele and labelled maistre, are omitted in this short report (Poulianos 1977, p. 545). However this kind of device is recorded in other oral testimonies from the Aegean (Damianidis 1996, p. 139-140, 1998, p. 218-219). It is mentioned that the boat builders used a device like a mould with very gently curve, almost a straight stick (like the Brazilian case) placed on the joint between the keel and the stempost and sometimes on the joint between the keel and the sternpost, if the boat is pointed at the stern (without a transom). This device was not necessarily at the position of a true frame and its purpose was to make the ribbands more rigid at the area were they had to change the curves of frames from convex to concave and to facilitate a sharper bending of the ribbands in order to meet the post (stem or stern). The position of this device could be slightly readjusted, by trial-and-error, in order to achieve the adequately fair curves of the ribbands.

It is noticeable that on both records (Greek and Brazilian) it is mentioned that these devices have almost the form of a straight stick. In Michele's drawings however this device, maistre, seems to have a convex shape. This difference is probably due to the variety of shape and geometry among the hulls. For the small pointed boats the rule that these devices are « almost straight sticks » is fairly accurate and mainly very practical. For the galleys though, with narrow and flat-bottom hulls, perhaps these devices had to have a convex shape and be controlled by some additional measurements. Thus Michele, trying to be analytical in the data that he provides, gives specific measurements for the shape of these devices, namely maistre. It is obvious that these measurements are taken either from an existing hull or from a vessel seen currently under construction.

Another interesting point is that the Greek boat builders name these devices (and sometimes the tail-frames as well)

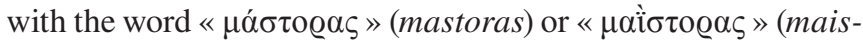
toras) (plural mastori or maistori). This is very similar to Michele's maistre and with an obvious root from the Byzantine word « $\mu \alpha \hat{i} \sigma \tau \omega \varrho$ » which had the meaning, according to the sources, of the director of an artistic performance and in particular the director of a church choir!

The other method of moulding, recorded recently in Greece, contains moulds with adjustable templates (Damianidis 1996, p. $140-153,1998$, p. 219-232). Ribbands are again used for the determination of the final position of the moulded frames and the configuration of the rest of the frames on the bow and the stern (fig. 2). They are basically used in the same way as the previous descriptions (upper ribbands are placed on both sides and the rest below on the one side only) but there are cases where they use more than three ribbands on one side, especially on big vessels. Once the ribbands have been given the final shape, a pliable metal rod is used to form the shape of each frame at its position marked (or notched) on the keel, the posts or the deadwood. The concept of the use of ribbands is the same as in the previous descriptions of «master frame and ribbands ». The only difference is that a number of adjacent frames are 


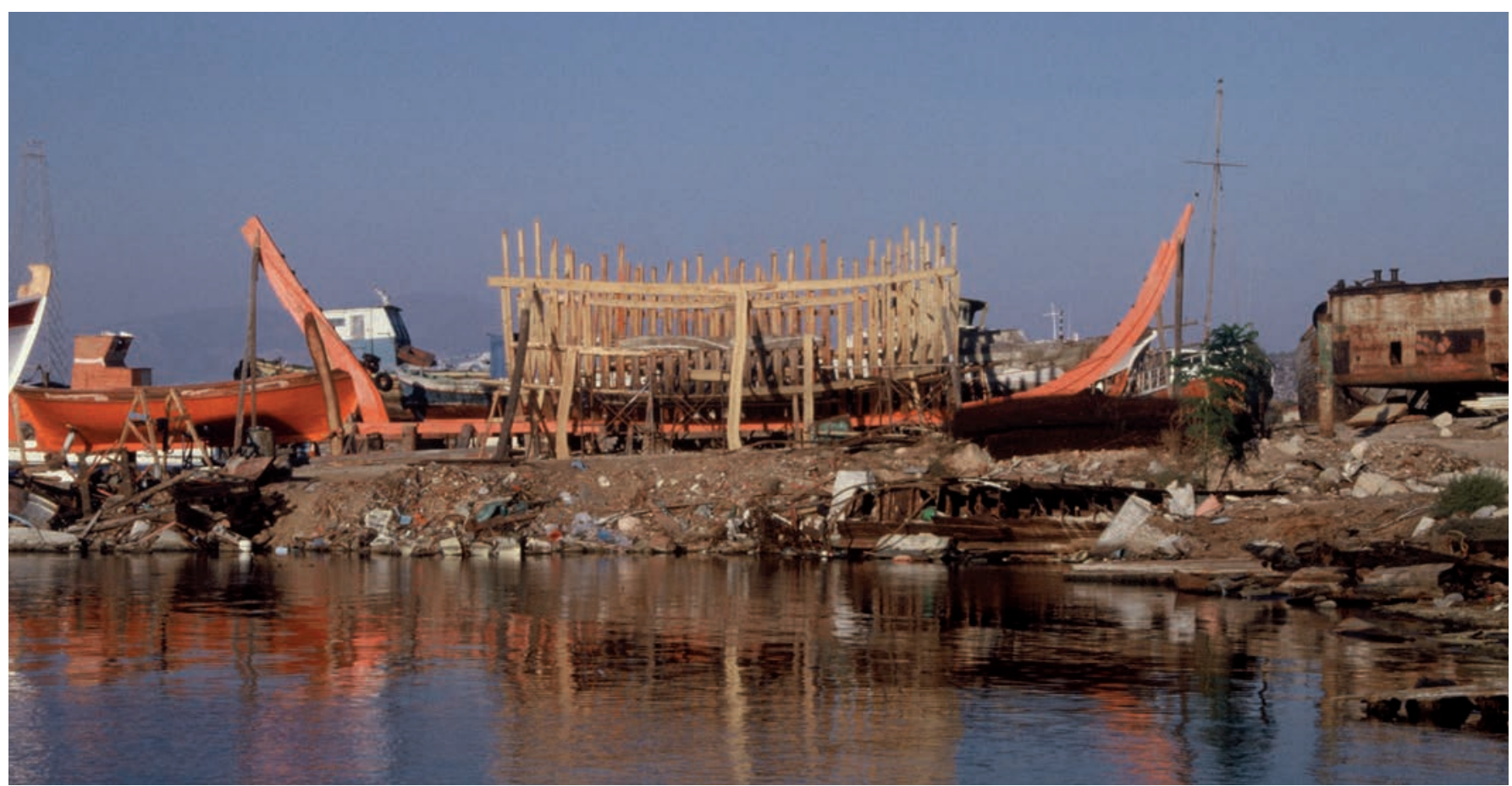

Fig. 3: Only the moulded frames on the middle part of the boat are erected. Ribbands of the second kind (scortsades) are placed as temporary keepers (or stabilisers) of the erected frames (photo K.A Damianidis, Salamis 1995).

pre-erected on the middle part of the hull before the ribbands are set up. However Greek boat builders often use the

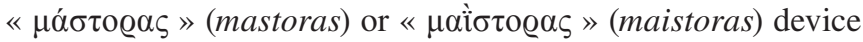
to determine the final position of the ribbands along the extremities of the hull. So this kind of device, maistre for Michele and mastoras or maistoras for the Greek boat builders seems to be an integral part of the use of this kind of ribband.

In all the Greek records the word for this kind of ribband is « with the same meaning in other shipbuilding traditions including Provence, Italy and Turkey (Kahane et al. 1988, p. 225), France (Rieth 2009b, p. 358-359) and it is also recently recorded in Tunisia with a reference to its early origin (Rieth 2011, p. 160).

The use of this kind of ribband is recorded in the traditional boatyards of Italy. In Sorrento and in Porto Torres of Sardinia the method of moulding with adjustable templates (called garbo, plural garbi) is recorded. Ribbands were used to determine the shapes of the frames in the extremities of the boats. Another method with fixed moulds for five frames placed on the keel at regular intervals is recorded in Lavagna in the Liguria region. Ribbands are placed on the moulded frames, from stern to stem and they are used to determine the shape of the rest of the frames (Marzari 1998, p. 201-208).

Ribbands were used in the French boatyards where they built vessels with the moulding method called gabarit de Saint-Joseph (Vence 1897, p. 25-31; Rieth 1996, p. 133-148). They use them, as in the other places, for the configuration of the shape of the frames at the extremities of the hull. Ribbands, called lisses, were placed after the erection of the moulded frames, on their outer surface, and extended to the stem and the sternpost. Lisse de construction was attested in French sources since 1494 and it is identified as synonym to forma, or formis in plural, which was attested in a contract specification (devis) for a construction of a huissier (horse - transport) by a Neapolitan master carpenter named Gratia (Rieth 2009b, p. 357-359). The frames located forward of the tail frame in the bow (couple de balancement avant) and aft of the tail frame in the stern (couple de balancement arrière) were shaped as tangent curves to the lines of the ribbands or lisses.

A similar method is recorded in the boatyards of Sfax, in the middle of the $20^{\text {th }} \mathrm{c}$., and in a boatyard on the island of Chergui (in the archipelago of Kerkenna, Tunis) during the years 2003 and 2005 (Rieth 2011, p. 153-177). According to the source for the boatyards of Sfax (Poujade 1946) the mould for the frames of the middle part of the boat was called stamenare and it was very similar to the French gabarit de Saint-Joseph. It is worth mentioning that the word stamenare has the same origin as the

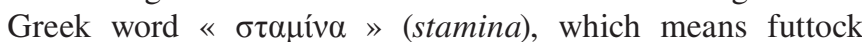
(Damianidis 1996, p. 186). Stamina seems to come from the

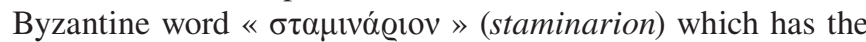
meaning of standing timber and this comes in turn from the verb «í $\sigma \tau \alpha \sigma \theta \alpha 1 »$ which has the meaning of stand up (Koukoules, 1950, p. 291-293). The moulding method from Sfax is related to the construction of a specific type of boat called kamaki of Greek origin used for fishing (perhaps sponge fishing). According to the staminare method there were ribbands employed to determine the shape of the frames at the extremities of the boat in a manner similar to the above-mentioned descriptions.

Concluding this kind of ribbands (determination of the overall shape of the hull) it is necessary that they should be flexible enough and adequate to materialize fair lines. Thus they are long laths with limited cross-sections made from soft wood (mostly pine) and with the lines of the grain running parallel to their length. In particular they should have the same natural characteristics as the planks of the vessel in order to represent adequately the required curves of the strakes to be placed later on. Bending is controlled by various methods including devices in the shape of frames but used only temporarily. It is recorded that sometimes the boat builders soaked this kind of ribbands in order to increase their bending ability (Poulianos 1977, p. 550). 


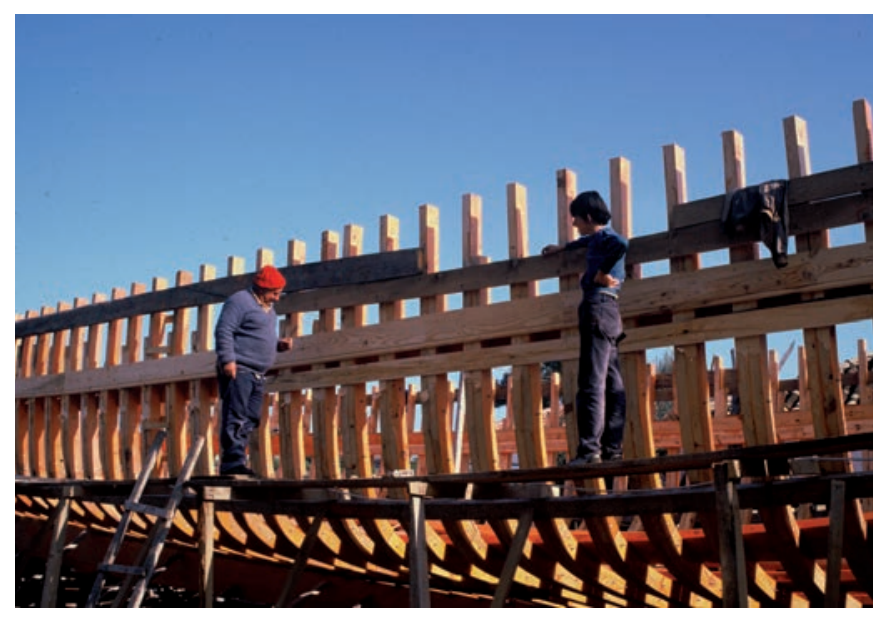

Fig. 4: A ribband of the third kind is placed on the frames in order to determine the bevel of their surface (photo K.A Damianidis, Spetses 1989).

\section{THE SECOND KIND OF RIBBAND}

In contrast to the first, the second kind of ribband has a totally different function and other characteristics. They are « temporary keepers » of the already erected frames, especially in the middle part of the hull. They are planks (stronger than the other kinds of ribband) firmly nailed but again temporarily on

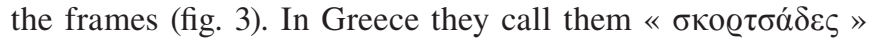
(scortsades) (Poulianos 1977, p. 545) and they are considered totally different from « $\varphi$ ó $\mu \varepsilon \varsigma$ », ribbands of the first kind. They are three or four planks nailed along the external surface of the frames and they are used especially to keep the frames in the right position at equal intervals until the permanent reinforcements, like the keelson, the clamps, the shelves and the external clamp strake set up on the skeleton. The main difference with the ribbands of the first type is the dimensions of their cross section and this is possibly an indication of their purpose since often they were mentioned with the same word ribbands, as in Richard Steffy's definition (Steffy 1994, p. 278). This probably causes some confusion in the interpretation of their function and lead to some erroneous conclusions about ribbands in general (Barker 1988, p. 539-559).

\section{THE THIRD KIND OF RIBBAND}

The third kind of ribband was used for the configuration of the final bevel on the external surface of the frames, before planking (fig. 4). The bevel on the frames is formed approximately during the determination of their shape, using the ribbands of the first kind. Once the skeleton of the vessel is completed (or it has taken its final rigid form) and before they nail any plank on the ribs, they trim again the external surface of the frames to form the final bevel angle at the position of each strake. For this task they use thin planks, as guides, placed at the position of the final planks on the frames. They are ribbands with the general meaning of the word and the Greek boat builders do not have any special name for them. Sometimes they use a rope instead of thin plank. They fasten the rope on the rabbets of the posts and nail it on some frames to form the sheer contour on the external surfaces of the frames. This rope determines the sheer of a strake and mainly the bevel on the

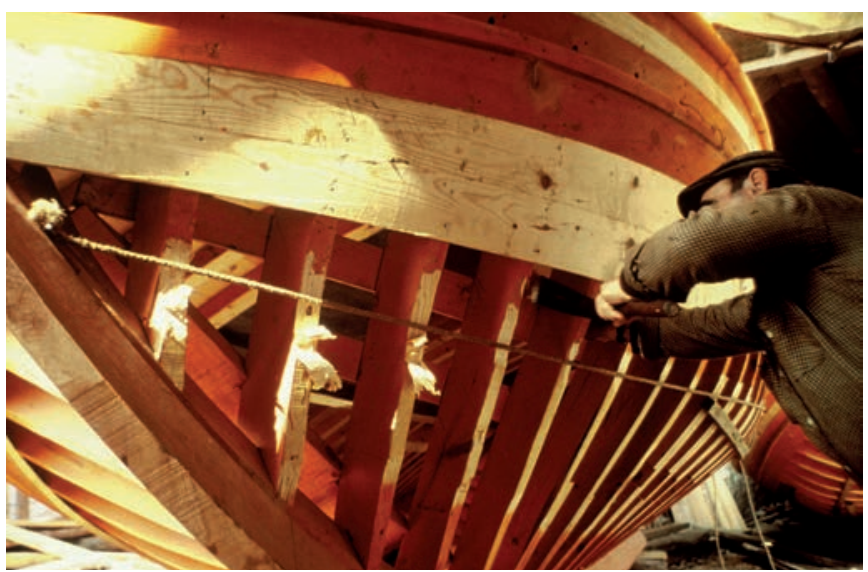

Fig. 5: A rope like a ribband of the third kind is used to determine the bevel of the frames. The boatbuilder trims the surface of the frames with an adze (photo K.A Damianidis, Perama 1984).

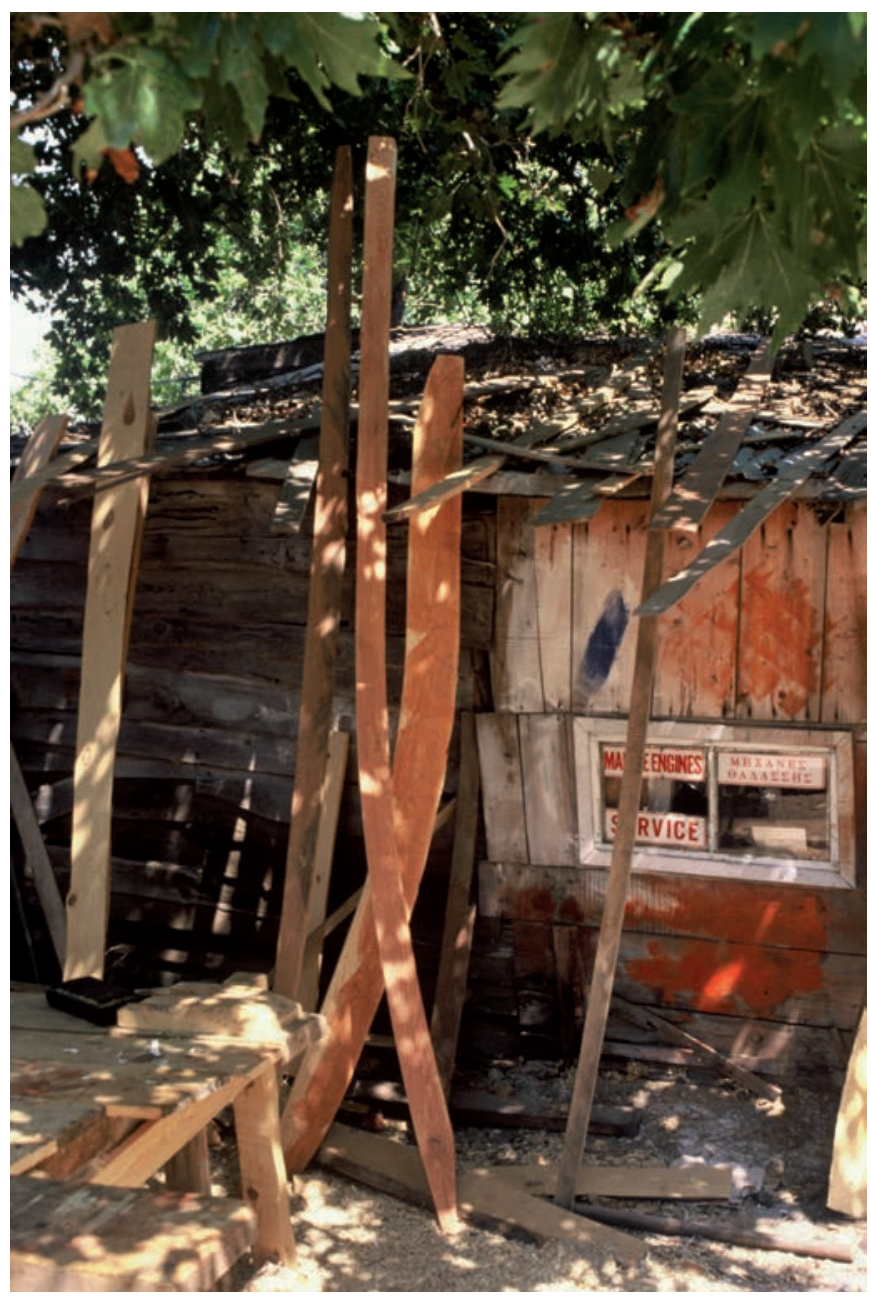

Fig. 6: Ribbands of the fourth kind (statzola) are placed aside after their use to determine the shape of planks (photo K.A Damianidis, Samos 1990).

frames and it is used as a guide for trimming the surfaces with an adze. The boat builder, following the line of the rope, uses his eye to find out when the curvature is fair and when a particular rib requires more trimming (fig. 5). Ribbands of this third kind are undoubtedly part of the configuration of the final ship-shape since the bevels on the frames are significant aspects for the fairness of the hull. They are pliable planks or laths or 


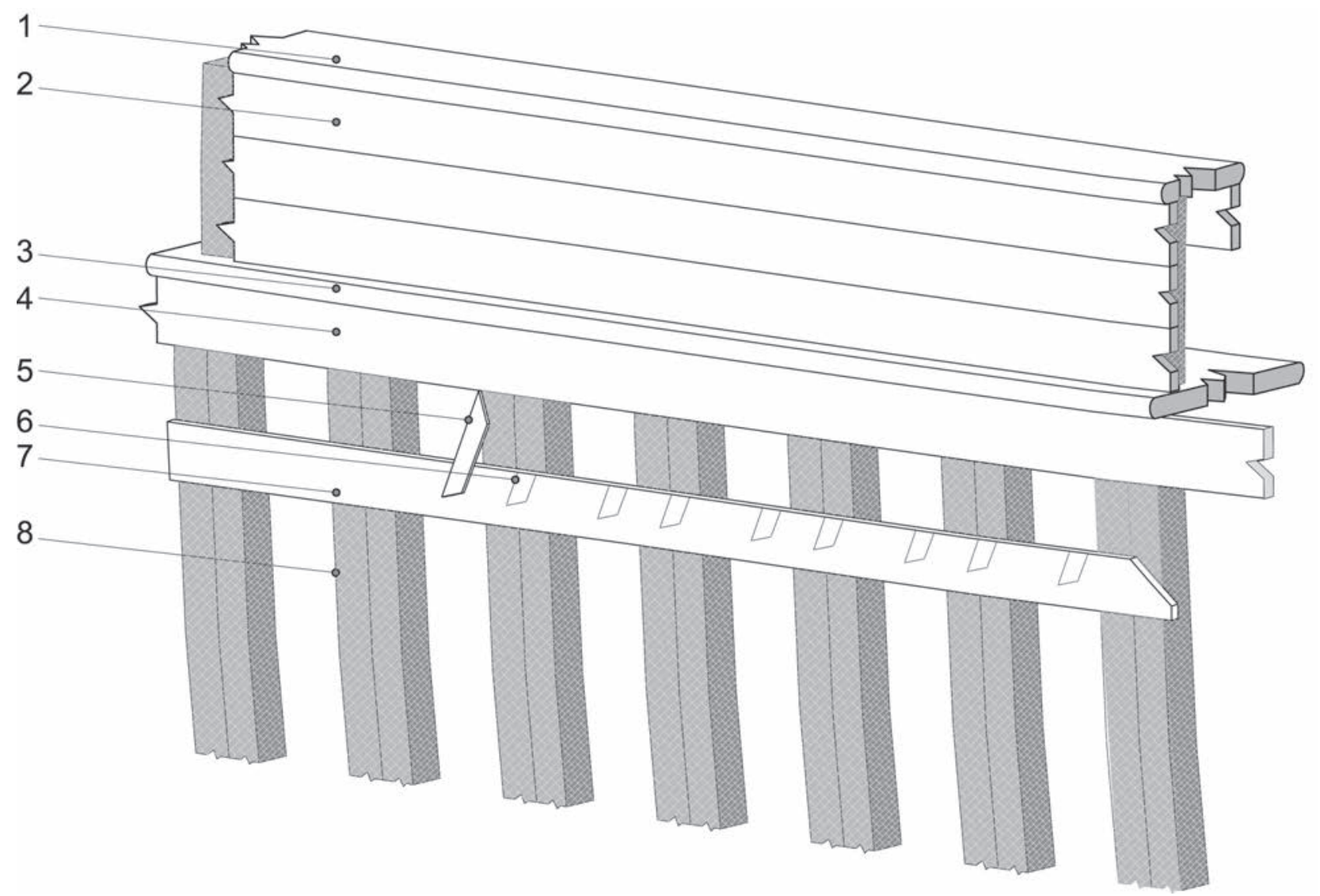

Fig. 7: Diagram of the use of the fourth kind ribband, called "statzola", and the small trapezoid wooden piece, like a gauge, called "mastari", in the process to copy the shape of the edge of the above plank. 1. Gunwale; 2. Sheer-strake; 3. Waterway timber; 4. Clamp strake; 5. "Mastari"; 6. The outline marks of "mastari" on the "statzola"; 7. "Statzola"; 8. Frames (drawing K.A. Damianidis).

even ropes nailed temporarily and used repeatedly all the way from the sheer strake to the keel.

\section{THE FORTH KIND OF RIBBAND}

The last kind of ribband was used during the final planking of the vessel. They were thin (about $1.5 \mathrm{~mm}$ ) pliable planks wide and long like the planks of the planking. They were in various shapes following the shapes of the potential planks of the hull (fig.6). For the middle part they were straight and for the extremities of the hull they were cut in curved shapes. This

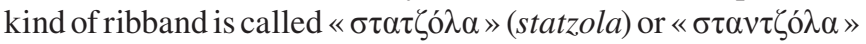
(stantzola) or « $\sigma \tau \alpha \zeta \dot{0} \lambda \alpha »($ stazola) in Greek and it was used together with a small trapezoidal wooden piece, like a gauge, called « $\mu \alpha \sigma \tau \alpha \rho i ́$ » (mastari) or « $\mu \pi \alpha \sigma \tau \alpha \delta i ́$ » (bastadi) (Poulianos 1977, p. 550; Damianidis 1991, p. 98, 1996, p. 203). The ribband, statzola, was nailed temporarily on the frames at the position where the plank after the next one will be located. They then place the small trapezoidal piece, mastari, on it and point one of the narrow angles of it to the edge of the plank above at certain points. Each time that this mastrari is pointed to the edge of the upper plank they mark the outline of the other end of it on the surface of statzola. By repeating this marking at several points of the edge of the upper plank they copy the whole line of the upper edge (fig. 7). Later in a reverse process they mark the recorded points on the planking stock. Then they link these points by a marking line and so they have the upper edge of the next plank ready to be sawn. This task, known as spiling, is repeated for all the planks of the planking and in this way the fourth kind of ribband was used to determine the shape of the strakes rather than the frames.

A similar method is used in the boatyards of the Turkish Black Sea coast. This kind of ribband is called sacula in Turkish and it has the same characteristics as the Greek statzola (Çoban, Damianidis 1988, p. 320).

\section{CONCLUSIONS}

It is obvious that material from ethnological sources often enlightens obscure aspects of past technology, either because elements of some old techniques have survived through oral tradition or because traditional solutions of some old technical problems can highlight similar practice from past societies. This is the case of the use of ribbands in the process of « designing » or « controlling » or « forming » the shape of the old wooden boats during their construction. Ribbands are some of the most significant aids for the configuration of the shape of some boats, even, possibly, more than the moulds for the frames. However they are not included, naturally, in the remnants of the shipwrecks and they are not even identified, normally, by footprints on the survived timbers, with the exceptions of some of them like the Red Bay Basque shipwreck (Grenier et al. 1994, p. 139). Nevertheless we cannot deny that they should be among the first elements that were 
introduced in the shipyards in order to visualize the initial concept of a vessel. This is confirmed by the contents of some early documents and shipbuilding treatises. Furthermore, as it is presented above, the various kinds of ribbands were significant aids for the determination of the shapes of several individual elements of the construction. Ribbands are aids of a « shell oriented » nature and as we have seen their shapes and positions are directly related to those of the strakes. However it is hard to consider that ribbands could be used without a supporting structure as described above. So they seem to be important aids, « shell oriented » to visualize a concept of a hull but in a context where they are supported by a basic structure. Perhaps they should be considered initial elements of a mixed strake-and-frame construction-method that apparently needs further research.
The apparent absence of suggestions from the studies of most of the shipwrecks concerning the use of ribbands could be overcomes by some ethnological research including the analysis of the oral shipbuilding tradition.

\section{ACKNOWLEDGMENTS}

Many thanks owned to Richard Barker, Giulia Boetto and Eric Rieth for their corrections and commentary during reading the original text.

Kostas A. DAmianidis kostasdamia@gmail.com

\section{REFERENCES}

ANDERSON R.C.

1925 Italian Naval Architecture about 1445, The Mariner's Mirror, 11.2 , p. $135-163$.

1945 Jal's Memoire no. 5 and the Manuscript Fabrica di Galere, The Mariner's Mirror, 31.3, p. 160-167.

BARKER R.A.

1986 Fragments from the Pepysian Library, Revista da Universidade de Coimbra, vol. XXXII, p. 161-178.

1988 Many may peruse us': ribbands, moulds and models in the Dockyards, Revista da Universidade de Coimbra, Vol. XXXIV, p. 539-559.

1998 English shipbuilding in the sixteenth century: evidence from the process of conception and construction, dans Rieth (dir.) 1998, p. 109-126.

2003 A Venetian Ship Drawing of 1619, in Nowacki, Valleriani (eds.) 2003, p. 67-76.

2007 Two Architectures - a view of sources and issues, in H. Nowacki, W. Lefèvre (eds), Creating shapes in civil and naval architecture, vol. I, Berlin, Max Planck Institute for the History of Science, Preprint 338, p. 41-133.

BASCH L.

1972 Ancient Wrecks and the Archaeology of Ships, IJNA, 1, p. 1-58.

Bellabarba S.

1993 The Ancient Methods of Designing Hulls, The Mariner's Mirror 79, p. 274-292.

Boetto G.

2006 Les navires de Fiumicino (Italie): architecture, matériaux, types et fonctions. Contribution à l'étude du système portuaire de Rome à l'époque impériale, $\mathrm{PhD}$ thesis, Université de Provence, Aix-en-Provence (unpublished).

Bondioli M.

2009 Early Shipbuilding Records and the Book of Michael of Rhodes, in P.O. Long, D. McGee, A.M. Stahl (eds), The Book of Michael of Rhodes: A fifteenth - century Maritime Manuscript, Cambridge MA, The MIT Press, p. 243-280.

BONINO M.

2012 Evidence of Geometric Operators used to Shape Ancient Hulls, IJNA, 41.1, p. 120-133.

\section{CARrel T.}

2003 From Forest to Fairway: Hull Analysis of « La Belle » a Late 17th Century French Ship, PhD thesis, University of St. Andrews, St. Andrews Scotland.
Chiggiato A.

1991 Contenuti Delle Architecture Navali Antiche, Rivista dell'Ateneo Veneto, 178, p. 141-211.

Çoban H., Damianidis A.K.

1988 Comparative study of the planking technique in the Aegean and the Southern Black Sea, in K.A. Damianidis (ed.), Shipbuilding and ships in the Eastern Mediterranean during the $18^{\text {th }}$ and $19^{\text {th }}$ centuries, Chios, Homerion Cultural Center of Chios Municipality, p. 315-324.

Contente Domingues F., Barker R.A.

1991 The Author and his Work, in F. Contente Domingues, R. A. Barker (eds), Fernando Oliveira, "Livro da fabrica das naos », Academia de Marinha, Lisbon, p. 37-47.

DAMIANIDIS A.K.

1991 Planking up a carvel boat in the Aegean, in R. Reinders, P. Kees (eds), Carvel construction technique: Skeleton-first, Shell-first. Proceedings of the Fifth International Symposium on Boat and Ship Archaeology (ISBSA 5), Amsterdam, 1988, Oxford, Oxbow Books (Oxbow Monograph, 12), p. 97-102.

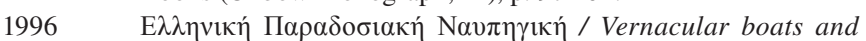
boatbuilding in Greece, Athens, ETBA.

1998 Methods used to control the form of the vessels in the Greek traditional boatyards, in Rieth (ed.) 1998, p. 217-244.

Grenier R., Loewen B., Proulx J-P.

1994 Basque Shipbuilding Technology c. 1560-1580: The Red Bay Project, in C. Westerdahl (ed.), Crossroads in Ancient Shipbuilding, Proceedings of the Sixth International Symposium on Boat and Ship Archaeology (ISBSA 6), Roskilde, 1991, Oxbow Books (Oxbow Monograph, 40), p. 137-141.

HARPSTER M.

2009 Designing the $9^{\text {th }}$ century AD vessel from Bozburun, Turkey, IJNA, 38.2, p. 297-313.

2010 Designing the $11^{\text {th }}$ century AD vessel from Serçe Limanı Turkey, IJNA, 39.1, p. 44-55.

HASSLÖF O.

1963 Wrecks, archives and living tradition, The Mariner's Mirror, 49, p. 162-177.

JAL A.

1840 Archéologie Navale, Paris, Arthus Bertrand.

Kahane H., Kahane R., Tietze A.

1988 The Lingua Franca in the Levant, reprinted by Artun Altiparmak, Istanbul. 
Koukoules Ph.

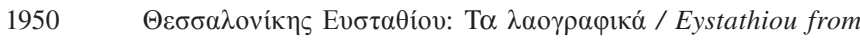
Thessaliniki: The Folkloric, Athens, Society for Macedonian Studies.

LANE F.C.

1934 Venetian ships and shipbuilders of the Renaissance, Baltimore, Johns Hopkins University Press.

Lehmann Th. L.

1995 Baldissera Quinto Drachio: Visione del Drachio, Amsterdam, De Gouden Reaal, second edition.

LOEWEN B.

1998 Recent Advances in Ship History and Archaeology, 1450-1650: Hull Design, Regional Typologies and Wood Studies, Material Culture Review, 48, p. 45-54.

2001 The Structures of Atlantic shipbuilding in the $16^{\text {th }}$ century. An archaeological perspective, in Proceeding of the International Symposium on Archaeology of Medieval and Modern Ships of Iberian-Atlantic Tradition, Lisbon, 1998, Lisbon, Instituto Portugues de Arqueologia (Trabajos de Arqueologia, 18), p. 241-258.

2007 Renaissance Hull Design: The Seeds of Modern Naval Architecture, in R. Grenier, M-A. Bernier, W. Stevens (eds), The Underwater Archaeology of Red Bay: Basque Shipbuilding and Whaling in the $16^{\text {th }}$ Century, Vol. 3, The 24M Hull, Parks Canada, p. 1-13.

MARZARI M.

1998 Evolution of shipbuilding techniques and methodologies in Adriatic and Tyrrhenian traditional shipyards, in Rieth (dir.) 1998, p. 181-215.

McGee D.

2009a The Shipbuilding Text of Michael of Rhodes, in Nowacki, Lefèvre (eds) 2009, p. 223-249.

2009b The Shipbuilding Text of Michael of Rhodes, in P.O. Long, D. McGee, A.M. Stahl (eds), The Book of Michael of Rhodes: A Fifteenth - century Maritime Manuscript, Cambridge MA, MIT Press, p. 211-242.

McKee E.

1983 Working Boats of Britain, London, Conway Maritime Press Ltd.

NOWACKI H., LEFÈVRE W. (EDS)

2009 Creating Ships in Civil and Naval Architecture. A CrossDisciplinary Comparison, Leiden-Boston, Brill (History of Science and Medicine Library, 11).

Nowacki H., Valleriani M. (eds.)

2003 Shipbuilding Practice and Ship Design Methods From the Renaissance to the $18^{\text {th }}$ Century, A Workshop Report, Berlin, Max Planck Institute for the History of Science, Preprint 245.

Özsait Kocabaș I., Kocabaș U.

2008 Technological and constructional features of Yenikapi shipwrecks: A preliminary evaluation, in U. Kocabaș (ed.), The Old Ships of the New Gate, Istanbul, Zero Prod. Ltd, p. 97-183.

Pomey P.

1998 Conception et réalisation des navires dans l'antiquité, in Rieth (dir.) 1998, , p. 49-72.

2009 On the Use of Design in Ancient Mediterranean Ship Construction, in Nowacki, Lefèvre (eds) 2009, p. 49-63.

Pomey P., Kahanov Y., Rieth É.

2012 Transition from Shell to Skeleton in Ancient Mediterranean Ship-Construction: analysis, problems, and future research, IJNA, 41.2, p. 235-314.
Poujade J.

1946 La route des Indes et ses navires, Paris, Payot.

Poulianos A.,

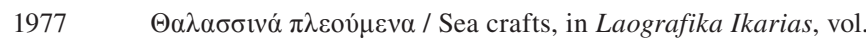
C', Athens, Etairia Laografikon kai Istorikon Meleton Ikarias, p. 525-595.

Pulak C., Ingram R., Jones M., Matthews S.

2013 The shipwrecks of Yenikapi and their contribution to the study of ship construction, in Z. Kiziltan, G. Baran Çelik (eds), Stories from the hidden harbor shipwrecks of Yenikapi, Istanbul, Istanbul Archaelogical Museum Press, p. 22-34.

RIETH É.

1996 Le maître-gabarit, la tablette et le trébuchet. Essai sur la conception non graphique des carènes du Moyen Âge au $x X^{e}$ siècle, Paris, Editions du CTHS.

2003a La méthode moderne de conception des carènes du wholemoulding, une mémoire des chantiers navals méditerraneens du Moyen Âge, in Nowacki, Valleriani (eds.) 2003, p. 17-32 (reprinted from Neptunia, 2000, p. 220).

2003b First Archaeological Evidence of the Mediterranean Whole Moulding Ship Design Method: The Example of the Culip VI Wreck, Spain (XIIIth-XIVth c.) in Nowacki, Valleriani (eds) 2003, p. 9-16.

2009a «To Design » and « to Build » Mediaeval Ships ( $5^{\text {th }}$ to $15^{\text {th }}$ centuries). The Application of Knowledge Held in Common with Civil Architecture, or in Isolation?, in Nowacki, Lefèvre (eds) 2009, p. 119-145.

2009b From Words to Technical Practices: Moulds and Naval Architecture in the Middle Ages, in Nowacki, Lefèvre (eds) 2009, p. 349-366.

2011 Construction d'une barque de pêche à Sfax, Tunisie, en 1939, une enquête ethnographique inédite de Jean Poujade, Archaelogia Maritima Mediterranea, 8, p. 153-177.

RIETH É. (DIR)

1998 Concevoir et construire les navires. De la trière au picoteux. Technologies, Idéologies, Pratiques, Ramonville Saint-Agne, Éditions Erès (Technologies/Idéologies/Pratiques, Revue d'anthropologie des Connaissances, vol. XIII, 1).

SARSFIELD J.P

1988 Master Frame and Ribbands: A Brazilian Case Study with an Overview of this Widespread Traditional Carvel Design and Building System, in R. Reinders, P. Kees (eds), Carvel construction technique: Skeleton-first, Shell-first. Proceedings of the Fifth International Symposium on Boat and Ship Archaeology (ISBSA 5), Amsterdam, 1988, Oxford, Oxbow Books (Oxbow Monograph, 12), p. 137-145.

STEFFY J.R.

1991 The Mediterranean shell to skeleton transition; A Northwest European parallel?, in R. Reinders, P. Kees (eds), Carvel construction technique: Skeleton-first, Shell-first. Proceedings of the Fifth International Symposium on Boat and Ship Archaeology (ISBSA 5), Amsterdam, 1988, Oxford, Oxbow Books (Oxbow Monograph, 12), p. 1-9.

1994 Wooden Ship Building and the Interpretation of Shipwrecks, College Station, Texas A\&M University Press.

1995 Ancient scantling: the projection and control of Mediterranean hull shapes, in H. Tzalas (ed.), Tropis III, Proceedings of the $3^{\text {rd }}$ International Symposium on Ships Construction in Antiquity, Athens, 1989, Athens, Hellenic Institute for the Preservation of Nautical Tradition, p. 417-428.

VENCE J.

1897 Construction et manceuvre des bateaux et embarcations à voilure latine, Paris, A. Challamel éditeur. 